\title{
RELIGION AND MEDICINE: THE CHOLERA PAMPHLETS OF OXFORD, 1832, 1849 AND 1854
}

by

\author{
R. J. MORRIS*
}

ONE BY-PRODUCT of the three great cholera epidemics of nineteenth-century Britain was a huge literature of pamphlets, reports and monographs which described the effects on individual towns and districts. ${ }^{1}$ In Oxford there were serious local outbreaks in 1832, 1849 and 1854. The disease spread along the Thames Valley from London and was brought into Oxford by the continual traffic of people and goods between the villages and the city, visitors to fairs and markets, and casual labourers seeking work or poor relief. Once cholera had arrived and established itself in Oxford it spread rapidly in the ill-drained low-lying parishes of St. Ebbe, St. Thomas, St. Clement and St. Aldate. The building boom of the 1820s and subsequent additions had filled the meadows and garden grounds along the banks of the Isis with hundreds of small two- or three-storey brick cottages. Their occupants were "chiefly working mechanics, small shopkeepers, journeymen, tailors, shoemakers and labourers with their wives and children."2 The drainage of these areas was by cesspool and the occasional culvert. This was ill suited to areas where the water table was always near the surface and where the Thames often flooded. As Thomas Allen, surgeon, described the situation in 1850: "In Oxford cesspools are not only general, they are universal; these sometimes burst and flood the yard with liquid filth . ..."3 Most of these cottages were supplied with water by shallow wells which, when they were not flooded by water which had burst from nearby cesspools, were liable to the seepage of sewage-tainted water from these cesspools and the privies and soakaways of property on higher ground around the High Street and St. Giles.4

The principal means of transmission of cholera was through water polluted by the excreta of affected patients. Thus the low-lying parts of Oxford provided the ideal environment for the disease to spread. In 1832, eighty-six people died. ${ }^{5}$ In 1849 , forty-four died, a reduction in part caused by the better drainage of the Jericho district. The total rose in 1854 to seventy-eight, some of the increase being due to the occupation of houses on the poorest land of St. Ebbe and St. Thomas which the builders had left until last. Although parts of Britain suffered from cholera in 1866, Oxford, with improved drainage and water supplies, was free. ${ }^{6}$ In Oxford, the deaths of 1832,1849 and 1854 were observed by a community of university and professional people who lived a few hundred yards away along the spine of the High Street and on the high ground north of Carfax. This community was in contact with, or contained members of the leading and most influential sections of British political, religious and scientific life. It provided the writers of three cholera pamphlets, one

*R. J. Morris, B.A., D.Phil., University of Edinburgh, Department of Economic History, 50 George Square, Edinburgh EH8 9JY. 
for each of the epidemics of 1832,1849 and 1854 . These pamphlets not only gave a detailed account of those epidemics but were characteristic of the literature which each epidemic produced.

The first pamphlet was written by the Rev. Vaughan Thomas. ${ }^{7}$ He was appointed chairman of the Oxford Board of Health which was formed in November 1831 in response to the directions of the Privy Council. ${ }^{8}$ Vaughan Thomas was already a well-known figure in Oxford life. He was a member of Corpus Christi College where he had been a Fellow until 1812. As a clergyman of the established church he held three livings, worth a total of $£ 1043$ a year, including Yarnton, a small village a few miles from Oxford. As a high tory and a church and king man, he opposed all changes in the institutions of church, state and university. In the elections for University M.P.s he voted for those who were opposed to Catholic Emancipation and in the 1830s he was an activist in the campaign which ensured that Oxford retained religious tests for all students who wished to matriculate. ${ }^{9} \mathrm{He}$ had a strong belief that the stability, justice and welfare of society depended upon maintaining a structure of power and authority based on tradition. This belief was the motivation for him to contribute so much time and energy towards keeping the Oxford Board of Health in operation. He had to overcome first the hostility between Town and University, then apathy, and finally the mutual jealousy of the thirteen parishes of Oxford, but by the end of 1832 he finished with praise from all sides. ${ }^{10}$ Vaughan Thomas believed in a paternalistic state, linked to an established church and working through the gentry and clergy. His argument for a welfare state began with the six acts of mercy and compassion set forth by Christ as recorded in the Gospel of St. Matthew. It was one of the glories of the Protestant state established after the Reformation that these acts of piety, looking after the hungry, the thirsty, the homeless, the naked, the sick and the imprisoned was under the "superintendence of the law". "Lazarus is no longer left to casual observation and an uncertain dole. He is protected by the public power. He is invested with personal rights. . . This great scheme of charitable jurisprudence is an emanation and an evidence of our holy religion ... all the greater debts of charity are now systematically paid out of the public treasury."11

In early nineteenth-century Britain these principles operated in minor ways like the visitation of prisons by chaplains and magistrates, but the main agent of paternalism under the law was the old poor law, which the Vicar of Yarnton defended against "the charlatannerie of political and statistical empires", by which he meant Malthus and his followers. ${ }^{12}$ Vaughan Thomas had written his pamphlet on the epidemic to celebrate the manner in which Oxford had acted to help the sick. In part his report was a calendar of social prestige. The members and the work of "numerous committees" were listed; the subscribers of money and even those who had given old clothes to the House of Observation were listed. ${ }^{13}$ Each name recorded Christian duty done and affirmed its holder in the higher and middle ranks of hierarchical society. The Oxford Board of Health had worked not only with a voluntary subscription 


\section{R. J. Morris}

but also by raising money on the poor rate, thus demonstrating that the "charity of public law" which the Malthusians condemned, was as necessary as private charity, and vindicating Vaughan Thomas's "charitable jurisprudence".

When the Oxford Board of Health met on 27 August 1832, "the chairman urged the duty of deriving instruction from the sad and painful experience,"14 with a view to preparing a report, which eventually became the pamphlet published in 1835 . The basis of instruction was an attempt to explain the nature and incidence of cholera. In attempting this Vaughan Thomas displayed a blend of moral and physical explanation which was to be expected of a man who had developed in the shadow of Archdeacon Paley's Natural theology, and who believed in "the reciprocating fitness of the constitution and condition of the universe, to the constitution and condition of man". ${ }^{15}$ Within this system the Almighty "binds and loosens the influence of infected atmosphere and the bands of epidemic disease", 16 with a number of distinct purposes in mind. Disease was a punishment for sin. As Vaughan Thomas said of the cholera, it illustrated "the reality of that universal law of Providence, whereby sin produces its own punishment, by which the Almighty punishes the wicked by the instrumentality of their own arts, and the consequences of their own excesses ... . [for] vicious indulgences predisposed the body to take disease." ${ }^{17}$ Sickness gave Christians an opportunity to aid suffering; it also made them aware of the power of God and demonstrated the common humanity and weakness of all members of society; "the liabilities of all to sicken, and to sink under febrile contagion should begat a community of purpose in all." 18 The great power of natural theology was its ability to unite moral, social and scientific concerns in the same inquiry and give a coherence of purpose to actions based on that inquiry. Vaughan Thomas advised the Board of Health to look "for moral and religious guidance as to vicious indulgences, imprudent negligences and generally as to things done or omitted either positively or probably injurious to health". After surveying the "peculiarities of the soil, situation, water and atmosphere" of the areas worst affected, he blamed the disease on bad drainage, crowded housing, lack of ventilation, dirty streets and "the destitute state of the poor". He recommended better street cleansing, improved sewers and water supply, and "the amelioration of the conditions of the poor". 19

This sounded like a comprehensive plan of public health reform, but the only positive action which resulted from the cholera experience was an attempt to improve the condition of prostitutes in the parishes of St. Ebbe and St. Thomas, who had suffered greatly during the epidemic, and to reform them through Magdalene institutions. Thus again the moral and the physical were linked together.

In November 1849, the Ashmolean Society of Oxford heard a paper by Thomas Allen, "On the progress of cholera in Oxford". In 1854 this paper was combined with a report by W. A. Greenhill on the mortality and diseases of Oxford and published by the Society. ${ }^{20}$ Greenhill and Allen were local surgeons, though linked in various ways with the university. Their report was not an isolated response to forty-four deaths but part of a continuing public health debate within Oxford City. This debate 


\section{The cholera pamphlets of Oxford, 1832, 1849 and 1854}

began effectively with a paper, "On the sanitory condition of Oxford", presented to the Ashmolean Society in 1848 by W. P. Ormerod. ${ }^{21}$ His paper, later published by the society was an essential prelude to the work of Greenhill and Allen.

Ormerod had been elected as surgeon to the Radcliffe Infirmary in 1845 and became a member of the Ashmolean Society a year later. ${ }^{22} \mathrm{He}$ was able to use the increasing amount of information coming from government departments and parliamentary inquiries. His main statistics came from the Registrar-General, and he claimed, "the plan followed is arranged according to the conclusions of the Metropolitan Sanitory commission." 23 This body had reported earlier in the year. Under the guidance of Edwin Chadwick, it had proceeded under the assumption, "that certain physical conditions promote both the intensity and extension of such disease". ${ }^{24}$ The commission reported on the administration and construction of drainage in the London area. They investigated the incidence of cholera in 1832; of typhus between 1845 and 1846; and of influenza during 1847-1848. They inspected a tabular summary of a perambulation of the suburban areas which had been made for them, and compared the results to show that the damp, humid and low-lying areas were the worst environments for disease. The three reports were a firm catalogue of the virtues of egg-shaped sewers, and the danger of basing policies on the theory that disease was spread by contagion. Ormerod followed some of the methods of these reports in his paper of 1848. He summarized the Registrar-General's information for Oxford for the years 1844-1846. The death rates were then compared with the whole of the country. Ormerod examined in detail the death rates for more diseases than those considered by the Metropolitan Sanitory Commission. He found that Oxford was in excess of the national average especially in the zymotic diseases such as typhus, cholera and other fevers. He felt that this result "deserves the most careful consideration, insomuch as that class contains those diseases which are especially diminished by sanitory measures". ${ }^{25}$ The comparison between the parishes within Oxford showed that St. Ebbe's and St. Thomas's were the worst affected. This tabulation was backed up by a street-by-street survey of the city which itemized all the conditions which Ormerod, following the Metropolitan Commission, believed were the causes of disease: poor paving, confined yards, slaughter-houses and pigsties, foul drains, "the large depository of sweepings and nightsoil amounting to several tons" near Hythe Bridge, earthen cesspools and unclean roads. ${ }^{26} \mathrm{He}$ hoped that action needed to pave the poorer streets and cover the open drains would be taken when recommended by a report produced in the shadow of the approaching cholera.

In many ways the work of Greenhill and Allen continued that of Ormerod. Although Allen's paper was given in 1849, and the reports on mortality and disease started the same year, publication of both was delayed until 1854. Greenhill's work was principally an analysis at local level of the Registrar-General's figures. He tabulated and presented the figures for cause of death month by month and made annual summaries. Much of this seems to be the collection and presentation of facts for their own sake. He wanted to establish accurately what was happening, and corrected faults in Ormerod's estimate of Oxford's population, and criticized the exaggerations of witnesses to the sanitary inquiry held in Oxford in $1851 .{ }^{27}$ Like Vaughan Thomas, 


\section{R. J. Morris}

Allen gave a chronicle of the cholera epidemic, but there the resemblance ended. No lists of subscriptions or members of committees were published. Instead there was a carefully tabulated statistical summary of the epidemic, and then a street-bystreet account of the cases, with a description of the condition of the areas affected. The statistics were presented to make comparisons possible, 1832 with 1849, parish with parish, and Oxford with other areas in England. For this purpose the death rate per thousand was used as a summary of the information. The figures effectively showed the parts of Oxford which needed improvement, St. Ebbe's and St. Thomas's again, with the addition this time of St. Peter-le-Bailey. The figures show that, unlike most of the country, Oxford suffered less in 1849 than in 1832. Allen was careful to point out that although Oxford's death rate from cholera in 1849, of 2.83 per 1,000, was below the 3 per 1,000 average for England, it was considerably above the 1.7 average for inland areas. ${ }^{28}$ Such comparisons were important for they were not only the basis for scientific discussion but provided material for political argument in the local public health debates.

G. A. Rowell was another member of the Ashmolean Society. He replied to Ormerod's pamphlet, claiming that it was misleading and was injuring the real interests of Oxford by promoting the opinion that, "Oxford, owing to its being in great part surrounded by low meadows, which are often flooded, is very unhealthy." ${ }^{29}$ Rowell showed that Ormerod had based his figures on 1846, a year of poor health for Oxford, when 569 people died (just under 400 being the usual number). By taking the period 1838-1844, Rowell found that one person in 50 died each year, a rate which compared favourably with Liverpool at 1 in 29 , Bradford at 1 in 40 , and even all England at 1 in 45.8. Rowell admitted that the concentration of poor health in certain areas of Oxford was the most serious aspect of the local situation. The political impact of this debate and the 1849 cholera persuaded the Paving Commissioners of Oxford City Corporation in December 1850 to employ Sir William Cubbitt to report on the sewage and water supply of the city. ${ }^{30}$ His report brought slow improvements in the 1850 s.

Both Ormerod and Allen presented their papers to the Ashmolean Society, which provided a focus for scientific discussion and acted as a channel of communication for scientific ideas, not only through meetings but also through the services provided by the library. The society had been founded in 1828 , "for the purpose of promoting within the University a taste for natural history, experimental philosophy, antiquarian and other branches of research". ${ }^{31}$ Its meetings were dominated by the two great figures of William Buckland, the geologist, and Charles Daubney, Professor of Chemistry, Botany and Rural Economy at Oxford. ${ }^{32}$ The papers and discussions ranged from mathematics and astronomy to geology and archaeology, with little interest in public health or medicine until 1843. That year Daubney, discussing a report on an institution for the cure of cretinism in Switzerland, reminded his audience of "the error of medical men ... that of imagining all epidemic and endemic diseases to follow the same laws; whereas the true philosophical mode of procedure would seem to be that of ascertaining their peculiar modes of propagation, by examining in detail the phenomena of each respectively". ${ }^{33} \mathrm{He}$ felt that with more systematic study doctors would see that cholera was spread by contagion, and was quite different 


\section{The cholera pamphlets of Oxford, 1832, 1849 and 1854}

from smallpox and typhus. The society had ignored the cholera in 1832, but interest was aroused by the second epidemic and by local public health activity. The first sign was Ormerod's paper of March 1848. ${ }^{34}$ This was followed in June by R. S. Hoggar, a civil engineer, who spoke "On the drainage of Worcester meadows and the adjoining parts of Jericho". ${ }^{35}$ In October 1849 the society discussed the theory that cholera was caused by a fungus and in November they heard the paper by Thomas Allen. ${ }^{36}$

Through the meetings of the Ashmolean Society, Ormerod, Greenhill and Allen were exposed to many examples of systematic observation, of discussion over the correlation of differing types of observation and arguments over cause and effect. After 1837 the meteorological figures from the Radcliffe Observatory in Oxford were published regularly in the Proceedings, and in 1843 the society set up its own anemometer and rain gauge on the roof of the Radcliffe Infirmary. ${ }^{37}$ In 1848 Rowell lectured on the value of simultaneous meteorological observations. ${ }^{38}$ It is impossible to separate how much the society was a crucial influence, and how far it was merely representative of pressures felt in other ways. The study of epidemics had been influenced by meteorology since the days when Clanny had watched the flashes of lightning over Sunderland. ${ }^{39}$ The question of the validity of correlation as an indicator of cause-effect links was important at several meetings. In October 1849 Daubney showed the society drawings and specimens supplied by Swayne of Bristol supposed to show cholera fungus which had been obtained from the rice-water evacuations of cholera patients. Acland admitted such bodies were present in the evacuations, but refused to assign them as the specific cause of cholera; two things occurring together were not evidence of a cause-effect link, he said. ${ }^{40}$ When Ormerod presented his paper to the society he was faced by Professor Buckland who remarked that "the map of Oxford on which Mr. Ormerod had marked by colours the prevalence of the disease, was in fact a geological one, the unhealthy districts coinciding with the alluvial soil."41

One influence on the work of Ormerod, Greenhill and Allen was the growing statistical movement. The careful numerical recording of medical, social and environmental observations had been evident in a small number of reports on the 1832 epidemic. This tradition grew in importance with the founding of the London Statistical Society in 1834 and of several provincial societies in succeeding years. The methodology and ideas of the movement were spread through the publication of the London Society's Journal in 1839, by the publication of a series of major government-sponsored public health reports, and of the annual reports and statistical series of the Registrar-General of Births, Deaths and Marriages which both began in $1839 . .^{42}$ These publications were summarized in newspapers and in the medical periodicals, but within the Ashmolean Society their influence filtered down to professional and scientific investigators who might apply them locally.

Ormerod admitted the influence of the Metropolitan Commission, and Buckland mentioned the 1842 report in the discussion of Daubney's paper in 1843. The society had both volumes of the 1845 Health of Towns Commission in its library. Thus in many ways the society made the pamphlet writers aware of the new ideas, methods, issues and information necessary for "examining in detail the phenomena of disease", as Daubney had recommended. 
The application of statistical methodology to public health was best demonstrated in the annual reports to the Registrar-General by William Farr, assistant and compiler of statistical abstracts. He wanted to get an accurate record of the facts so that, by comparing statistics from different parts of the country and from population with different social and environmental characteristics, he could devise general rules from which it would be possible to deduce methods of improving the health of the poor. ${ }^{43}$ Farr never intended to work in isolation in the Registrar-General's office and suggested that others should study their local areas and then compare their results with other districts: "The inhabitants will thus learn from authentic documents, the relative sanitory state of their neighbourhood; the causes of disease will be discovered, and suggestions which may lead to numerous improvements will be pressed upon the attention of the resident proprietors and authorities." 44 The three Oxford medical men followed Farr both at the general and the particular local level. They tried to use their results to formulate general rules. They noted, somewhat irrelevantly, that "marriage returns serve as a sort of barometer to the prosperity of the country", but more usefully suggested that Oxford's records showed the truth of the law which stated that when the death rate is higher after the summer solstice, then the overall death rate is high. In winter, pneumonia and like diseases killed the old and weak, whilst the summer fevers were deadly enough to kill strong and weak alike. Better housing and drainage conditions could reduce the effect of these summer fevers. Both "laws" come from the Registrar-General's reports. ${ }^{45}$ The Oxford report on the 1849 epidemic also began to correlate cholera statistics with other information. The authors found little relationship between cholera and occupation, but a strong link between cholera and poverty; 122 out of 144 cases were "proper objects of charity", as were 140 out of 174 in $1832 . .^{46}$ The Oxford doctors then went on to use these local findings and their implications as part of a campaign for the improvement of drainage, cleansing, sewerage and water supply in Oxford.

\section{III}

The memoir of the cholera at Oxford in the year 1854 was written by Henry Wentworth Acland, Lee's Reader in Anatomy in the University. This Memoir was one of the few major local studies published after the third epidemic. It was more important and gained much wider recognition than the other pamphlets on Oxford. Acland already had high status within the medical and scientific community. Anything he wrote was bound to attract more notice than the works of parsons and town medical practitioners. A substantial and widely researched work, the Memoir gained praise from medical and lay periodicals. ${ }^{47}$

In Acland's work the two streams of thought involved in the preceding local studies were combined; the religious and moral concerns of Vaughan Thomas, and the statistical and scientific method of Greenhill and Allen. Acland combined the religious and scientific approach to the epidemic with a powerful and effective prose style and a wide scope which gave his Memoir far greater importance than the earlier accounts. Henry Wentworth Acland came from a Devon landed family. His father was a Canningite Tory who had married a lady with the strict views of the Clapham 
evangelicals. A gentleman's education sent him to Harrow, Christ Church, to the dissecting rooms of St. George's Hospital in London, and to study under Alison at Edinburgh. In 1845 he was made Lee's Reader and Fellow of All Souls. His upbringing among the philanthropic evangelicals with their belief in worship, personal discipline and hard work had a strong influence on his reaction to medical education. He was appalled by the poor quality of much hospital teaching and detested the coarse and indelicate attitudes of many students towards the bodies they dissected for study. In a pamplet written whilst still a student Acland spelt out his belief that the medical student should approach his subject matter with the reverence due to the work of God. ${ }^{48}$ As Lee's Reader, he worked to improve the teaching and quality of medical education at Oxford. In the 1850s he followed Queckett's example at London and introduced the microscope into medical studies. When he was elected Regius Professor of Medicine to follow Kidd in 1857 the Lancet, a periodical not noted for its kindness to the established authorities of the medical world, gave him unstinted praise, notably for his work since 1845, making the Christ Church museum "the best teaching museum for comparative anatomy and physiology in England". ${ }^{49}$ Acland's training and beliefs were well suited for combining the medical and scientific with the religious and moral in his analysis of the epidemic. ${ }^{50}$

Acland's analysis was based on a more extensive and careful record of observable facts than anything the men of 1848-1849 had used. As soon as he was consulted by the Oxford Board of Health, Acland distributed forms to all local doctors asking for daily returns of new cases, giving the names, residence, age, and hour of seizure of victims; the form for the weekly return asked for sex, occupation, premonitory symptoms, treatment and outcome of each case. ${ }^{51}$ Manual Johnson, the Radcliffe Observer, gave Acland a wide range of meteorological data including rainfall, atmospheric pressure, cloud cover, force and direction of the wind and ozone content of the air. ${ }^{52}$ Acland also used information from the other pamphlet writers and from the 1851 census. This then was his raw material. As much as possible was carefully tabulated so that the reader might compare different areas, different epidemics, and the day-to-day movement of all variables. The basic method of analysis was an exercise in correlation by simple inspection of the tables. He found that in Oxford the incidence of cholera was inversely related to altitude, and positively related to the density of population; both relationships were suggested to him by the work of Farr and of the General Board of Health. ${ }^{53} \mathrm{He}$ found that women were more likely to get cholera than men, but could see no link between liability to the disease and occupation. He warned that the sample size was too small in Oxford to get a large enough number of cases for a reliable conclusion on this. ${ }^{54}$ He shows the same caution in using correlation as he had shown at the Ashmolean Society discussions. The readings of the ozonometer rose sharply around 17-25 September and 3-9 October coinciding with the major and minor peaks of the cholera epidemic. Acland noted this but felt that more records were needed before claiming the coincidence as significant. ${ }^{65}$ The practical implications of an inconclusive body of statistics showed in Acland's attitude to choosing the mode of treatment. Most doctors used a mixture of opium and chalk, others used sulphuric acid. Early in the epidemic Acland used alternating doses of castor oil and olive oil. Two of the three patients he treated in 


\section{R. J. Morris}

this way recovered, but he stopped using this method when the Medical Council of the Board of Health published "larger statistics" which showed the damage caused by this treatment. Acland warned of the "fallaciousness of percentages on small data". He came to favour the sulphuric acid treatment, but admitted success "proves no more than that the treatment did no harm". "Ample statistics collected from competent observers" were needed to prove or disprove any conclusions. ${ }^{58}$ Although science was "inconclusive", he felt that the physician must "act manfully upon the greater probability". Scientific judgement was reserved; awaiting more data, but the immediate medical decision had to be taken on the basis of probability. ${ }^{57}$

His study of the nature of cholera showed the contemporary preoccupation with etiology. His own theoretical standpoint seemed to be that of a modified miasmatist. ${ }^{58}$ Acland's Memoir showed how deep and sophisticated was the influence of miasmatic theory in the middle years of the nineteenth century, and how necessary the theory was for interpreting the evidence which came to the doctors. Acland recognized the value of Snow's theory that cholera was communicated by water polluted by cholera patients' excreta. ${ }^{59} \mathrm{He}$ knew of the work of Budd, and of Swayne in Bristol. ${ }^{60}$ These theories could not explain the occurrence of isolated cases, like that of the farm labourer in the remote country village of Oakley who was struck down whilst working in the field. Acland plotted the first thirty cases of cholera in Oxford on a sketch map to show many scattered through the city with no communication between them. ${ }^{61}$ The simple form of the miasmatic theory, that the smell of decomposing organic matter or some sort of "exhalation" from low-lying and ill-drained places were the causes of disease, finds no place in Acland, though it still existed in medical minds in Oxford, for he quotes Mr. Hitchings, surgeon, "In Maizey's yard the air was quite oppressive with the smell of cholera." 22 Some of the measures which Acland took and recommended were those of a miasmatist. He recorded knocking holes in the roof of one house to improve ventilation. He joined the interminable calls for better drainage and cleansing, and for the substitution of sewers and closets for privies and cesspools. Like many miasmatists his recommendations were none the less valuable for being based on incorrect theory. Acland modified the simple theory in two ways. He accepted that once cholera had established itself it might spread by contagion in the manner Snow had suggested. This had happened in the Gas Street area where sixteen of the first thirty cases had occurred. By the end of the 1854 epidemic he recommended that the evacuations of all cholera patients should be destroyed with strong acid or caustic alkali. On 29 September 1854 Acland was called to the County Gaol. There had been five cases and four deaths since the epidemic started. He found that the gaol drew its water from the nearby stagnant mill tail of the Castle Mill, just below the outfall of the prison drain. The prison governor shut off this supply of water and the gaol suffered only one more case throughout the epidemic. Acland acted differently in 1849. He inspected the prison, found it clean, and recommended measures to improve the diet. The prison had fifteen cases, but with ten recoveries. ${ }^{63}$ The contrast between Acland's behaviour in 1849 and 1854 showed how Snow's discovery was having an impact on medical practice. Faced with a practical problem, Acland followed the ideas of Snow, although at heart he was a miasmatist. In a quiet way the history of cholera at the Castle Gaol was a demonstration of Snow's theory, 


\section{The cholera pamphlets of Oxford, 1832, 1849 and 1854}

as convincing as the incident of the Broad Street pump. Acland also sought to develop the miasmatic theory in conjunction with the meteorological data in order to explain why the isolated and scattered cases occurred when they did. Atmospheric pressure was greater than normal in the three cholera years, but temperature variations seemed to have little pattern. His efforts to find some significant link in this mass of observable data had small success. "How few similar features the three years possess," he complains. ${ }^{64} \mathrm{He}$ hints at an ingenious way of meeting those objectors to miasma who argued that whilst everyone was subject to changes in the atmosphere, only a few caught the disease. Acland noted complaints of a general looseness of the bowels throughout Oxford between August and October. At one end of the scale the constipated man found he no longer needed the aloetic pill before dinner, at the other end were the unfortunate cholera cases. "Is it not perfectly explicable", he asks, "by some abnormal condition of the surrounding atmosphere, or of the imponderable agents which act in some yet unravelled way on animal organisms?"65 The powerful directing influence of miasma theory was leading Acland on fruitless paths of scientific inquiry.

The mixture of evangelical religion and scientific training which guided Acland produced clear moral attitudes on all matters affecting the epidemic, including his own work. Like Vaughan Thomas, he saw the cholera as divine punishment; "communities as well as individuals may violate the sanitary laws which our creator has imposed on us; and the consequences of the violation of these laws is punishment to the community for its common crime." influenced his upbringing, he believed in the great power for good of an educated and moral upper class. He felt Oxford had a special part to play in this by informing the clergy and gentry educated there of "the laws of health". "When the Professors who teach these subjects [chemistry, physiology, hygiene] have made their purpose felt through the hearts and the heads of the upper classes, how much good, and content, and gratitude, may not spring up in the hearts of even the most hopeless members of the body politic." 67 In the dedication of the Memoir Acland promised to examine, "the moral and physical evils that endanger or increase epidemic". The description of some of the patients he visited showed his concern for the sheer animalism of the victims, their poverty, but above all for the vision of the eternal soul in danger.

Soon after five one morning a woman awoke in the agony of cramps with intense and sudden collapse. She was seen at six. There was in her room no article of furniture but one broken chair; no bed of any kind, no fire, no food; she lay on the bare boards; a bundle of old sacking served for a pillow; She had no blanket for any covering but the cotton clothes she had on. She rolled, screaming. One woman scarcely sober sat by, with a pipe in her mouth, looking on ... . in the hospital she died. Her room was cleaned out: the woman that cleaned it had next night the cholera. She and her husband were drunk in bed. The agony sobered her, but her husband went reeling about the room: in a room below were smokers and drinkers. Then a woman of the streets in her gaudiness came to see her. They would not hear reason, but drank more spirits. The victim of the disease cried out to the end that her soul was everlastingly lost; and she died. ${ }^{\circ 8}$

The style of the hell-fire sermon, the town missionaries' appeal and the sanitary reports all contribute to this passage. Although he saw the epidemic as the will of God this never led Acland to fatalistic acceptance of circumstances. He identified the will of God with the laws of science, so he believed that the individual endowed 


\section{R. J. Morris}

with free will could take sound practical action to avoid the punishment which cholera represented. Because Acland saw moral and physical evils together, his long-term remedies never relied on moral exhortation alone, or sanitary reform alone. He wanted sanitary reform to be accompanied by a wide programme of religious, educational and intellectual improvement. He was strongly influenced by Chalmers, the Edinburgh evangelical minister who wrote The Christian and civic economy of large towns ${ }^{69}$ in describing the great part which voluntary organizations sponsored by the upper and middle classes could play in improving society; societies like the Oxford Working Men's Institution were doing the essential work of spreading and guiding religion, education and recreation among the working classes.

The purpose of the cholera pamphlet literature as exemplified in the Oxford series was to seek an explanation and to learn the lessons of a series of alarming and disruptive crises in British public health. The general pattern of development was clear. Vaughan Thomas used a religious-based explanation and added casual observations on urban environmental conditions. Ormerod, Greenhill and Allen used systematic observation which implied political action but made few other moral comments. Acland then proceeded to merge the religious and the scientific approach. The religious element was not residual, for Acland developed a more thorough analysis of the cholera, from both perspectives, in his Memoir. His statistics were better organized and more factors were subjected to quantifiable observation. His religious and moral analysis was not restricted to the Poor Law and the fate of prostitutes but ranged over the responsibility of the university in changing ruling-class attitudes to public health and finished with a discussion of the place of voluntary societies in changing and spreading values among the working classes.

Each pamphlet was an improvement in understanding and technique on that which had gone before, but the series was written at a time when medical research in Britain was falling behind that in Germany. This has been attributed to the development of a series of competing universities in Germany using research schools as part of a battle for prestige and status. ${ }^{70}$ The writing of the cholera pamphlets showed that new institutional foci were developing in Britain for medical research, namely the London and provincial medical societies and government agencies like the RegistrarGeneral's office. These were all closely linked either with medical practice or with the political problems of sanitation and quarantine, often with both. Hence the collection of huge amounts of data concerning the etiology of disease as well as the preoccupation with case histories and anatomy; the first exemplified in the cholera pamphlets, the second, crucial for the practising doctor, in the medical periodical press.

The improving techniques for the study of epidemics from Ormerod to Acland showed to perfection the ability of nineteenth-century medical research to gather quantifiable facts without really knowing which facts were relevant to cholera. During the 1832 epidemic the contagion theories had been replaced by a miasmatic paradigm. This had served officials and medical men well until by 1854 it began to break up 


\section{The cholera pamphlets of Oxford, 1832, 1849 and 1854}

under the weight of evidence which it could not explain. Acland displayed the theoretical weakness of the miasmatic paradigm on its own terms. He showed that it did not and could not tell him what to measure or what to observe. "Miasma" had sent him to meteorological data without result, and produced laws about altitude and population density without assigning a cause. Under the mass of evidence he had produced, the miasmatic theory had to be so far adapted by the inclusion of contingent contagion and other qualifications that it had begun to be nearly indistinguishable from the contagionist point of view.

The appearance and development of religious and moral observations in Acland were of major importance. His writing demonstrated that religious and scientific attitudes were not incompatible or mutually exclusive in the manner which $T$. $H$. Huxley and some modern sociologists have suggested. Nor was the merging of the sacred and profane in the same mind on the same subject only the result of a powerful personality with an upbringing that bred respect for both traditions, for moral and religious references were a distinctive feature of English medical texts in the midnineteenth century. ${ }^{71}$ Nor did the overt presence of religious perspectives within scientific thinking appear to hamper progress in the manner which has been suggested for geological and evolutionary theories. ${ }^{72}$ The inadequacies of miasmatic theory hampered Acland far more than his religion. Some of the reason for the power of theology in the thoughts and actions of Vaughan Thomas and Acland lay in their common origins. They were both sons of country gentlemen. They had followed a common path for the younger sons of the gentry and entered the upper ranks of one of the old professions. They came from families who accepted the duty of supporting the whole social structure through the actions of magistrates, poor laws, charities, voluntary societies and a whole series of other relationships between the classes and interests of Britain, and religion justified, supported and encouraged their efforts. Both men faced the task of co-ordinating and sustaining a wide range of social actions by doctors, ratepayers, councillors and others which they believed essential for the correct working of stable society. Their scientific theory was weak, a poor basis for persuading a ratepayer to part with his money, so that duty under God was the basis for motivation. Through government and the many local medical institutions, the close links between research medicine and political and social action in epidemics, public health campaigns and voluntary societies meant that the close partnership of religion and science was possible, indeed essential, for many engaged at the highest levels of medical research. God did not fill the gaps in science but sustained an ideal, a vision, of how to act in support of a stable and worthwhile society in normal times, and in the face of threats like cholera.

\section{REFERENCES}

1. Charles Creighton, A history of epidemics, Cambridge University Press, 1891, vol. 2, 793-862: N. Longmate, King Cholera, London, Hamish Hamilton, 1966; E. Ashworth Underwood, 'The history of the cholera in Great Britain', Proc. R. Soc. Med., 1948, 41 : 165-173.

2. A report of the evidence taken before $T$. MacDougal Smith into the state of the sewerage, drainage and water supply of Oxford . .., Oxford, 1851, p. 50ff.

3. Ibid., p. 53. 


\section{R. J. Morris}

4. R. Fasnacht, A history of the city of Oxford, Oxford, Blackwell, 1954, p. 124; R. J. Morris, 'The Friars and Paradise: an essay in the building history of Oxford, 18011861', Oxoniensia, 1971, 36: 72-98.

5. Cholera returns in Great Britain, P.R.O., P.C.1/108.

6. Report on the cholera epidemic of 1866 in England, Parliamentary Papers, 1867-1868, vol. 37. This report gave information on deaths for 1849,1854 and 1866.

7. Rev. Vaughan Thomas, Memorials of the malignant cholera in Oxford, 1832, Oxford, 1835.

8. Jackson's Oxford Journal, 19 November 1831.

9. Gentleman's Magazine, 1858, ii: 645; 1859, i: 320; W. R. Ward, Victorian Oxford, London, Cass, 1965, passim.

10. Oxford Board of Health, Old Minute Book, MSS. Top Oxon c 271 and Minute Book, MSS. Top Oxon c 272, both in the Bodleian Library, Oxford; there is a fuller discussion of this epidemic in my forthcoming book, "Cholera 1832: a scourge for our sins'.

11. Vaughan Thomas, On the visitation of prisoners, an assize sermon preached at St. Mary's Oxford, 3rd March 1825, Oxford 1825.

12. Vaughan Thomas, op. cit., note 7 above, p. ix.

13. Ibid., pp. 2-4, 8-11 and 24 .

14. Minute Book of the Oxford Board of Health, 27 August 1832.

15. Vaughan Thomas, An address delivered at the Birmingham Royal School of Medicine and Surgery at the 3rd annual meeting, 29th August 1838, Oxford, 1838, pp. 19-21; William Paley, Natural theology from Works . ..., London, Thomas Allman, 1851.

16. Vaughan Thomas, Abound in this grace also, a sermon on co-operative charity preached ... in aid of a fund for erecting a fever ward at Queen's Hospital, Birmingham, 1845, p. 11.

17. Vaughan Thomas, op. cit., note 7 above, p. 22.

18. Vaughan Thomas, op. cit., note 16 above, p. 11.

19. Ibid., pp. 16-22 and iii-iv.

20. W. A. Greenhill and Thomas Allen, Report on the mortality and public health of Oxford during the years 1849 and 1850, Oxford, The Ashmolean Society, 1854. Appendix A which contained the account of the cholera was entitled, "On the social and sanitary condition of Oxford".

21. W. P. Ormerod, "On the sanitory condition of Oxford", Trans. Ashmolean Soc., 1848, 2: no. xxii, 1-59 and map. "Sanitory" is an erroneous spelling frequently used, see Oxford English dictionary.

22. Testimonials of W. P. Ormerod for the election of a surgeon to the Radcliffe Infirmary, Oxford, in Papers relating to the proceedings of the University, 1845, in the Bodleian Library, Oxford, p. 147; Proceedings of the Ashmolean Society, 1846, 2: no. 43, 113.

23. Ormerod, op. cit., note 21 above.

24. Metropolitan Sanitary Commission, Parliamentary Papers, House of Commons, 1847-1848, vol. 32.

25. Ormerod, op. cit., note 21 above, p. 12.

26. Ibid.

27. Greenhill and Allen, op. cit., note 20 above, p.v.

28. Ibid., pp. 29 and 32-33.

29. G. A. Rowell, The public health of Oxford as compared with other districts in England, Oxford, [n.d., probably 1850].

30. Oxford Paving Commissioners, Miscellaneous Papers, 1849-53, Oxford City Records, R.3.7; Sir William Cubbitt, Report on the sewage and water supply of Oxford, with an appendix by T. MacDougal-Smith, Amersham, 1851.

31. Rev. A. Hume, The learned societies and printing clubs of the United Kingdom, London, 1847, pp. 152-153; Rules of the Ashmolean Society, Oxford, [n.d.]. A note on the copy presented by F. A. Bellamy to the National Library of Scotland suggests 1850. 
32. See obituary notices of Buckland and Daubney in Proc. R. Soc. Lond., 1856-1857, 8: 264, and 1868-1869, 17: Ixxv.

33. Proc. Ashmolean Soc., 1843, 2: 24-25.

34. See note 21 above.

35. Ibid., 1848, 2: 189-190 and 199-202.

36. Ibid., p. 190.

37. Ibid., 1837, 1 : no. 13 ; and 1843, $2: 23$.

38. Ibid., 1836, 1: 10-11; and 1848, 2: 206.

39. W. Reid Clanny, Hyperanthraxis or the cholera at Sunderland, London, 1832, p. 3.

40. Op. cit., note 33, 1849, 2: 232; in 1854 Daubney rejected Swayne's theories, see ibid., 1854, 2: 49-41, and Charles Daubney, 'On the influence of the lower vegetable organisms in the production of epidemic diseases', Edinb. new philos. J., 1855, 2 (new series): 88.

41. Op. cit., note 33 above, $1848,2: 190$.

42. M. J. Cullen, 'Social statistics in Britain, 1839-1852', University of Edinburgh Ph.D. thesis, 1971; M. W. Flinn, introduction to Edwin Chadwick, Report on the sanitary condition of the labouring population of Great Britain, 1842, Edinburgh University Press, 1965, pp. 43-66.

43. William Farr, Vital statistics: a memorial volume of selections from his reports and writings, ed. by Noel A. Humphreys, London, 1885; First annual report of the Registrar-General, London, 1839.

44. Fourth annual report of the Registrar-General, London 1842.

45. Greenhill and Allen, op. cit., note 20 above, pp. 8 and v; Eighth annual report of the Registrar-General, London, 1848, pp. ix, xxvi and xxxiv.

46. Ibid., p. 30.

47. Med. Times, 1856, 33: 600; Lond. quart. Rev., 1867, 27 : 218-240.

48. J. B. Atlay, Sir Henry Wentworth Acland, a memoir, London, Smith, Elder, 1903, pp.3-109. A letter from a medical student on some moral difficulties in his studies, and on the duty of the state to aid in lessening them, published anonomously, 1841, and quoted by J. B. Atlay.

49. Lancet, 10 October 1857, p. 368; Charles Newman, The evolution of medical education in the nineteenth century, Oxford University Press, 1957, pp. 141-149, gives an account of the early campaign against the traditional authorities of English medicine, waged by Wakley as editor of the Lancet.

50. After the epidemic, Bishop Wilberforce wrote to Acland, "It quite revives my spirit to come on the thoughts of one like you to whom God has given at once a Scientific and Religious mind, the mind of a Christian Philosopher", quoted by Atlay, op. cit., note 48 above, p. 194.

51. H. W. Acland, Memoir on the cholera at Oxford in the year 1854, with considerations suggested by the epidemic, London, 1856, p. 92.

52. Ibid., pp. 53-67.

53. Ibid., p. 49; Fourth annual report of the Registrar-General, London, 1842, p. 15; Fifth annual report of the Registrar-General, London, 1843, p. 409; Report of the General Board of Health on the epidemic of cholera of 1848 and 1849, Parliamentary Papers, London, 1850, vol. 21, appendix B.

54. Acland, op. cit., note 51 above, p. 33.

55. Ibid., p. 65.

56. Ibid., pp. 71-72.

57. Ibid., p. 12.

58. M. W. Flinn, op. cit., note 42 above, pp. 62-63 and R. Lambert, Sir John Simon and English social administration, 1816-1904, London, MacGibbon \& Kee, 1963, pp. 49-50, give a summary of the debate on the communication and cause of disease at the beginning and end respectively of the $1840 \mathrm{~s}$. 


\section{R. J. Morris}

59. Acland, op. cit., note 51 above, p. 77; John Snow, On the mode of communication of cholera, London, 1849, 2nd ed. enlarged, London, J, Churchill, 1855, reprinted New York, 1936, with an introduction by Wade Hampton Frost.

60. See note 40; William Budd, Malignant cholera; its mode of propagation, London, 1849; the theory that cholera was spread by microscopic bodies of a fungoid nature was given very thorough examination in a survey article 'Evidence for the fungous origin of cholera', Edinb. med. surg. J., 1850, 73: 81-118.

61. Acland, op. cit., note 51 above, p. 21, plate II.

62. Ibid., p. 92.

63. Ibid., p. 51 ; Fifteenth report of the Inspector of Prisons to Great Britain, I-Home district, Parliamentary Papers, 1851, vol. 27, p. 46.

64. Acland, op. cit., note 51 above, pp. 57-63; Report of the Committee for Scientific Enquiries, Parliamentary Papers, 1854-55, vol. 21, has the results of a similar exercise by a more uncompromising group of miasmatists seeking to solve the problem "how the epidemic poisons are generated".

65. Acland, op.cit., note 51 above, p. 74.

66. Ibid., p. 105.

67. Ibid., p. 6; F. K. Brown, Fathers of the Victorians, Cambridge University Press, 1961, pp. 47 and 351.

68. Acland., op. cit., note 51 above, p. 48.

69. Thomas Chalmers, The Christian and civic economy of large towns, 3 vols, Glasgow, Chalmers \& Collins, 1821; Acland, op. cit., note 51 above, pp. 10 and 144; see also Rev. William Hanna, Memoirs of Thomas Chalmers, 2 vols., Edinburgh, Thomas Constable, 1854. The account of missionary work in the West Port area of Edinburgh is in the mainstream of the tradition of evangelical descriptive writing which influenced Acland's work.

70. Joseph Ben-David, 'Scientific productivity and academic organization in 19th century medicine', Amer. sociol. Rev., 1960, 25: 828-843; Gerald L. Geison, 'Social and institutional factors in the stagnancy of English physiology, 1840-1970', Bull. Hist. Med., 1972, 46: 30-58.

71. T. H. Huxley, Science and Christian tradition, vol. 5 of Collected essays, London, Macmillan, 1894, preface and prologue; C. Y. Glock and R. Stark, Religion and society in tension, Chicago, Rand McNally, 1965, pp. 9-11 and 263-289; S. Cotgrove and S. Box, Science, industry and society, London, Allen \& Unwin, 1970, pp. 53-55.

72. Bernard Barber, 'Resistance by scientists to scientific discovery', Science, 1961, 134: 595-602; C. C. Gillespie, Genesis and geology, Cambridge, Mass., Harvard University Press, 1951. 